\title{
Calibration of Hunters' Impressions with Female Caribou Body Condition Indices to Predict Probability of Pregnancy
}

\author{
P.O'B. LYVER' ${ }^{1}$ and A. GUNN ${ }^{2}$
}

(Received 7 March 2003; accepted in revised form 22 January 2004)

\begin{abstract}
Aboriginal harvests of barren-ground caribou (Rangifer tarandus) potentially offer a large sample for assessing body condition. The purpose of this study was to determine the probability that a certain amount of fat would be at designated anatomical sites when Dënesółine hunters qualitatively report the condition of an animal. Hunters' impressions were used to evaluate the condition of adult female barren-ground caribou (R.t. groenlandicus) in late winter. A semi-objective body condition index (BCI) was developed using fat indices described by biologists as useful for measuring caribou body condition. Fat deposits from 217 adult female caribou harvested in late winter (41 in 2000 and 176 in 2001) were used to calibrate hunters' impressions with BCI estimates. Variation in hunters' impressions and BCI estimates indicated that adult female caribou were fatter in 2000 than in 2001. Multinomial log-linear models indicated that hunters' impressions were related to each of the variables that make up BCI. The probability of pregnancy was significantly related to both BCI and hunters' impressions in 2000 and in 2001 . Both models indicated that fat adult female caribou had a greater probability of being pregnant than thin cows. Monitoring of barrenground caribou body condition provides common ground for northern aboriginal communities and government biologists to collaboratively manage a wildlife resource.
\end{abstract}

Key words: Dënesółine, caribou, body condition, hunters' impressions, pregnancy, herd well-being

RÉSUMÉ. Les prélèvements du caribou des toundras (Rangifer tarandus) par les Autochtones pourraient offrir un vaste échantillon permettant d'évaluer l'état corporel. Cette étude avait pour but de déterminer la probabilité qu'une certaine quantité de gras soit présente dans des zones anatomiques désignées, au moment où les chasseurs Dënesółine font un rapport qualitatif sur la condition physique d'un animal. On a eu recours aux opinions des chasseurs pour évaluer l'état physique du caribou femelle des toundras à l'âge adulte (R. $t$. groenlandicus) à la fin de l'hiver. On a créé un index semi-objectif de l'état corporel (IEC) en utilisant les indices de gras que les biologistes ont trouvés utiles pour mesurer l'état physique du caribou. Les dépôts de gras provenant de 217 caribous femelles adultes prélevés à la fin de l'hiver (41 en 2000 et 176 en 2001) ont servi à étalonner l'opinion des chasseurs par rapport à l'IEC estimé. Les variations entre l'opinion des chasseurs et l'IEC estimé ont montré que le caribou femelle adulte était plus gras en 2000 qu'en 2001. Des modèles log-linéaires multinomiaux ont révélé que l'opinion des chasseurs était reliée à chacune des variables composant l'IEC. En 2000 et 2001, la probabilité que la femelle soit en gestation était fortement corrélée à la fois à l'IEC et à l'opinion des chasseurs. Les deux modèles ont révélé que la probabilité que la femelle caribou adulte soit gravide était beaucoup plus grande pour les femelles grasses que pour les maigres. Le suivi sur la condition physique du caribou des toundras constitue une plate-forme commune propice à une gestion de la faune menée en collaboration par les communautés autochtones du Nord et les biologistes du gouvernement.

Mots clés: Dënesółine, caribou, condition physique, opinion des chasseurs, état de gestation, niveau de santé de la harde

Traduit pour la revue Arctic par Nésida Loyer.

\section{INTRODUCTION}

Community-based monitoring programs are becoming increasingly common in wildlife and environmental management. Biologists and managers representing government and industry are recognizing the value and long-term viability of involving indigenous user groups. A major advantage of community-based monitoring programs is their ability to combine user traditional knowledge with Western science- based information. This potential contribution to management is well recognized in northern aboriginal communities like Łútsël K'é that harvest Bathurst barren-ground caribou, Rangifer tarandus groenlandicus (Parlee, 1998).

Barren-ground caribou are one of the most valuable renewable resources in Canada's Northwest Territories (NT). They have immense cultural, nutritional, and biological value, and consequently the caribou harvest is of great importance to aboriginal hunter-gatherer groups in

\footnotetext{
${ }^{1}$ Natural Resources Institute, University of Manitoba, Winnipeg, Manitoba R3T 2N2, Canada; present address: Landcare Research, P.O. Box 69, Lincoln, 8152, Canterbury, New Zealand; lyverp@landcareresearch.co.nz

${ }^{2}$ Wildlife and Fisheries Division, Department of Resources, Wildlife and Economic Development, Government of the Northwest Territories, 600, 5102 - 50th Avenue, Yellowknife, Northwest Territories X1A 3S8, Canada; anne_gunn@gov.nt.ca

(C) The Arctic Institute of North America
} 


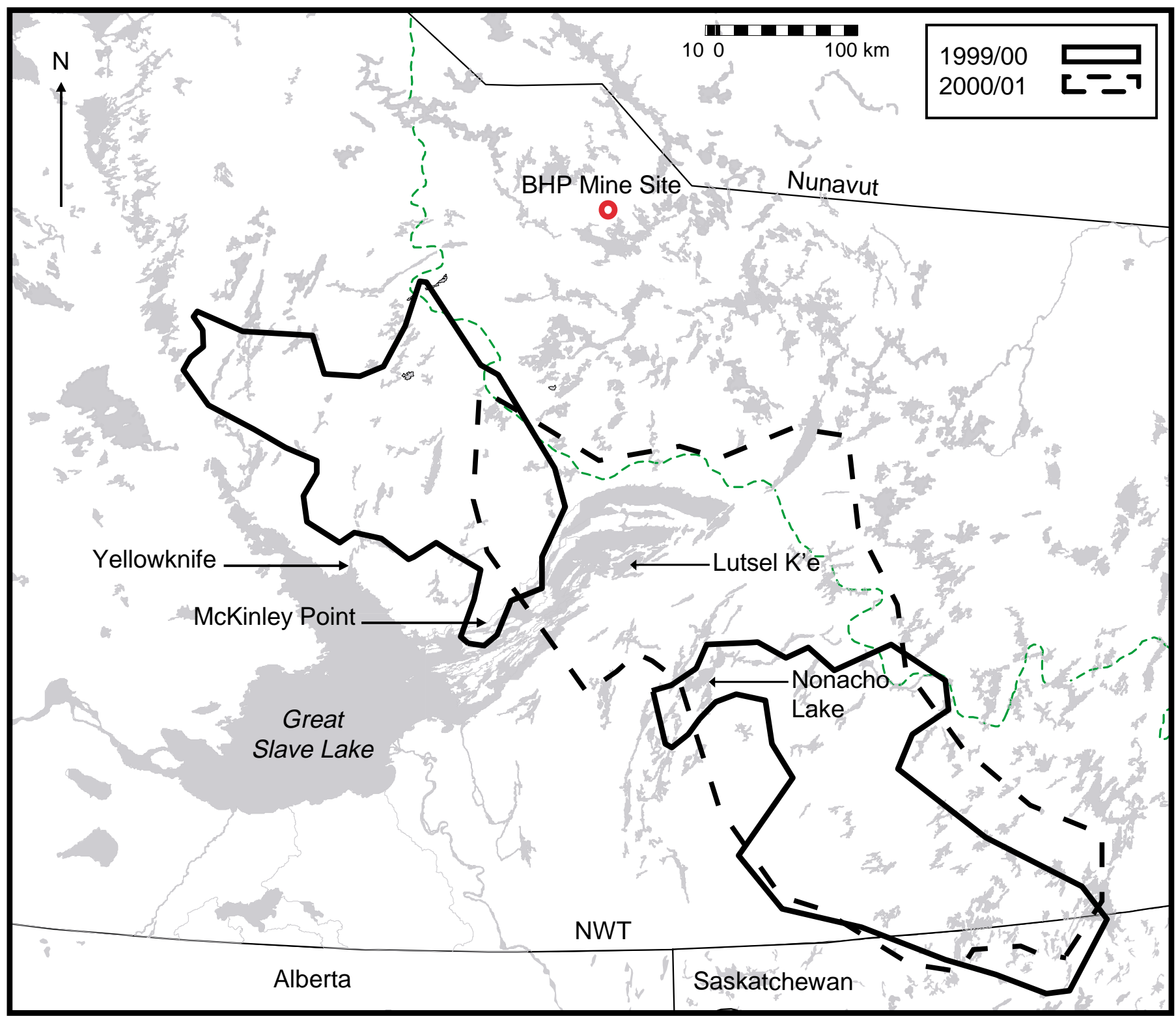

FIG 1. Location of Łútsël K'é and areas used by Bathurst caribou cows during winter (November to February) 1999-2000 and $2000-01$ (modified from Gunn et al., 2001).

this area (Smith, 1978; Berkes, 1998). Effective caribou management should be guided by ecological monitoring that includes aboriginal knowledge.

Both aboriginal people and scientists recognize caribou body condition as an important indicator of general herd condition (Kofinas et al., 2003). Body condition directly affects mortality, pregnancy, calf survival, age to first breeding, and breeding pauses in adult female caribou (Thomas, 1982; Cameron, 1994; Gerhart et al., 1996, 1997; Thomas and Kiliaan, 1998b; Allaye Chan-McLeod et al., 1999). Changes in caribou body condition may reflect environmental limitations to herd growth.

A community-based caribou monitoring system required body condition indices that would not be an imposition on hunters and would use their existing techniques to assess caribou condition. We did not want hunters to simply report on the status of fat at one or more anatomical sites because that was not customary. Rather, we wanted to ask hunters to use the method that they would normally use.

Our research objective was to calibrate hunters' qualitative impressions of harvested adult (two or more years old) female caribou condition with a semi-objective body condition index $(\mathrm{BCI})$, and in turn determine the relationship of each to pregnancy rates. This required developing a BCI from fat indices similar to those used in other caribou monitoring programs (Kofinas et al., 2001). It was thought that observer variation would be reduced if BCI parameters were used, especially if in the future a large number of observers from different communities were involved. Aboriginal hunters use a number of characteristics (primarily the fat indices measured in this study) to form an overall impression of caribou body condition. 
TABLE 1. Body condition indices established for adult female barren-ground caribou in the Northwest Territories during late winter (February-April) 2000-2001. Data were obtained from hunters' impressions of the animals' fatness and five measured fat deposits.

\begin{tabular}{|c|c|c|c|c|}
\hline \multirow[b]{2}{*}{$\begin{array}{l}\text { Index } \\
\text { Hunter Impression }\end{array}$} & \multicolumn{4}{|c|}{ Rating Score } \\
\hline & $\begin{array}{c}1 \\
\text { skinny }\end{array}$ & $\begin{array}{c}2 \\
\text { not so bad }\end{array}$ & $\begin{array}{c}3 \\
\text { fat }\end{array}$ & $\begin{array}{c}4 \\
\text { really fat }\end{array}$ \\
\hline \multicolumn{5}{|l|}{ Body Condition Index (BCI) } \\
\hline $\begin{array}{l}\text { Brisket fat depth (inches) } \\
\text { Back fat depth (inches) }{ }^{1} \\
\text { Stomach fat amount } \\
\text { Fat coverage of kidney }{ }^{2} \\
\text { Femur marrow }\end{array}$ & $\begin{array}{c}\text { none } \\
\text { none } \\
\text { none } \\
\text { none } \\
\text { red/runny }\end{array}$ & $\begin{array}{c}\text { up to } .5 \\
\text { up to } .5 \\
\text { some } \\
\text { some } \\
\text { pink/greasy }\end{array}$ & $\begin{array}{l}\text { more than } .5 \text { to } 1 \\
\text { more than } .5 \text { to } 1 \\
\text { covered } \\
\text { covered } \\
\text { cream/solid }\end{array}$ & $\begin{array}{l}\text { more than } 1 \\
\text { more than } 1 \\
- \\
- \\
-\end{array}$ \\
\hline
\end{tabular}

${ }^{1}$ Measured along the dorsal line about $5 \mathrm{~cm}$ forward from the base of the tail (Gerhart et al., 1996).

2 The amount of fat judged to be covering each of the kidneys.

Therefore, the probability that a certain amount of fat would be at designated anatomical sites when hunters refer to an adult female caribou as being in a particular condition was determined. Variation between the two study years in body condition predictions and pregnancy probabilities was also assessed.

\section{METHODS}

\section{Assessment of Caribou Body Condition}

The study was conducted from the Dënesóline (Chipewyan) community of Łútsël K'é $\left(62^{\circ} 24^{\prime} \mathrm{N}, 110^{\circ} 48^{\prime} \mathrm{W}\right)$, located in the east arm of Great Slave Lake, NT, Canada (Fig. 1). Three observers accompanied 36 Łútsël K'é hunters on hunting forays for caribou between mid February and late April in 2000 and 2001. An Inuit hunter from Baker Lake, two Yellowknife hunters from Dettah, and two Dogrib hunters from Fort Rae were also surveyed during this period in 2001, as they were hunting in the Łútsël K'é area.

The selection of each technique to measure body condition was based on ease of data collection, reliability of measure, ease of analysis, acceptability of the technique to local people, and cost of sampling. Two indices, hunters' impressions and a body condition index (BCI), were used to evaluate the body condition of each caribou. After preliminary discussions with hunters, a qualitative index was developed using their impressions of caribou body condition (Table 1). Hunters provided observers with an evaluation of body condition after dressing out each caribou in the field. The second index used was semi-objective. Scores were given to five body-condition categories and then summed (Table 1). BCI ratings for each caribou could range from 5 to 17 . Observers measured these fat indices as the hunter dressed out each animal. Brisket and back fat depths were recorded in inches because this provides easy-to-judge measurements and conforms to the protocol used in other hunter body-condition studies conducted around North America (Kofinas et al., 2003; Table 1). Back fat depth was measured along the dorsal line about $5 \mathrm{~cm}$ forward from the base of the tail (Gerhart et al., 1996). Kidney and stomach fat were the amount of fat judged to be covering each of these organs (Table 1). The pregnancy status of each adult female caribou harvested was also recorded.

\section{Analysis of Body Condition Indices}

Multinomial log-linear models (using the "multinom" function in the neural network S-Plus library, Venables and Ripley, 1997) were used to evaluate the relationship between hunters' impressions and individual body condition indices. For each body condition index (stomach, kidney, back, brisket, and marrow fat), four models were fitted and compared:

1. Body condition $=$ impression + year + impression $\cdot y e a r$ (i.e., the hunter's impression of an animal with the same body condition rating differs between years);

2. Body condition $=$ impression + year (i.e., the hunter's impression of an animal predicts the body condition rating, but the rating changes from year to year);

3. Body condition $=$ impression (i.e., impression predicts the body condition rating);

4. Null model (i.e., body condition is independent of impression or year).

These models were compared in the above sequence using likelihood ratio tests. If there was no evidence for an interaction (i.e., Model 1 vs. Model 2), then Model 2 was compared with Model 3. From this comparison, predicted values under "Model 3" were calculated. These values are the estimated probabilities that an animal with a given hunter's impression will have a particular body condition rating, ignoring year.

Some fat ratings were grouped for the multinomial loglinear models because of the small sample sizes. Initially, the hunter's impression index had four ratings (i.e., skinny, not so bad, fat, really fat). However, since hunters described only six adult female caribou as "really fat" over the two-year period, these animals were combined with those rated as "fat." Similarly, only one adult female 
TABLE 2. Relationships detected between body condition indices, hunters' impressions, and year using multinomial log-linear models. (Models were compared using likelihood ratio tests in the sequence outlined in the Methods section.)

\begin{tabular}{|c|c|c|c|c|c|}
\hline Body condition indices & Model & Test & df & Likelihood ratio statistic & Prob. $\left(\chi^{2}\right)$ \\
\hline Stomach fat & $\begin{array}{l}\text { Model } 1 \text { (Impression •year) } \\
\text { Model } 2 \text { (Impression + year) } \\
\text { Model } 3 \text { (Impression) }\end{array}$ & $\begin{array}{l}1 \text { vs. } 2 \\
2 \text { vs. } 3 \\
3 \text { vs. } 4\end{array}$ & $\begin{array}{l}4 \\
2 \\
4\end{array}$ & $\begin{array}{r}0.359 \\
1.807 \\
139.591\end{array}$ & $\begin{array}{r}0.986 \\
0.405 \\
<0.001\end{array}$ \\
\hline Kidney fat & $\begin{array}{l}\text { Model } 1 \text { (Impression •year) } \\
\text { Model } 2 \text { (Impression + year) } \\
\text { Model } 3 \text { (Impression) }\end{array}$ & $\begin{array}{l}1 \text { vs. } 2 \\
2 \text { vs. } 3 \\
3 \text { vs. } 4\end{array}$ & $\begin{array}{l}4 \\
2 \\
4\end{array}$ & $\begin{array}{r}1.930 \\
16.903 \\
64.664\end{array}$ & $\begin{aligned} & 0.749 \\
< & 0.001 \\
< & 0.001\end{aligned}$ \\
\hline Brisket fat & $\begin{array}{l}\text { Model } 1 \text { (Impression •year) } \\
\text { Model } 2 \text { (Impression + year) } \\
\text { Model } 3 \text { (Impression) }\end{array}$ & $\begin{array}{l}1 \text { vs. } 2 \\
2 \text { vs. } 3 \\
3 \text { vs. } 4\end{array}$ & $\begin{array}{l}4 \\
2 \\
4\end{array}$ & $\begin{array}{r}0.809 \\
13.221 \\
122.574\end{array}$ & $\begin{array}{r}0.937 \\
0.001 \\
<0.001\end{array}$ \\
\hline Back fat & $\begin{array}{l}\text { Model } 1 \text { (Impression •year) } \\
\text { Model } 2 \text { (Impression + year) } \\
\text { Model } 3 \text { (Impression) }\end{array}$ & $\begin{array}{l}1 \text { vs. } 2 \\
2 \text { vs. } 3 \\
3 \text { vs. } 4\end{array}$ & $\begin{array}{l}4 \\
2 \\
4\end{array}$ & $\begin{array}{r}1.165 \\
4.064 \\
184.772\end{array}$ & $\begin{array}{r}0.884 \\
0.131 \\
<0.001\end{array}$ \\
\hline Femur marrow & $\begin{array}{l}\text { Model } 1 \text { (Impression • year) } \\
\text { Model } 2 \text { (Impression + year) } \\
\text { Model } 3 \text { (Impression) }\end{array}$ & $\begin{array}{l}1 \text { vs. } 2 \\
2 \text { vs. } 3 \\
3 \text { vs. } 4\end{array}$ & $\begin{array}{l}2 \\
1 \\
2\end{array}$ & $\begin{array}{l}4.234 \\
0.615 \\
6.984\end{array}$ & $\begin{array}{l}0.120 \\
0.433 \\
0.030\end{array}$ \\
\hline
\end{tabular}

caribou had a brisket fat rating of more than 1 inch over the two years of sample collection; therefore, this rating was merged with the over .5 inch to 1 inch rating. The over 1 inch and over .5 inch to 1 inch ratings for back fat were also pooled because only eight female caribou had over 1 inch of back fat. No animals were rated as having "red/runny" femur marrow, so there were only two ratings (pink/greasy and cream/solid) for this category.

\section{Prediction of Pregnancy Probabilities}

The relationships between pregnancy and the two methods of assessing body condition (i.e., hunters' impressions and BCI) in 2000 and 2001 were examined using logistic regression models. To determine the best model to use, we assessed whether BCI was as good a predictor of pregnancy as the original variables from which it was derived. We fitted two models, one relating pregnancy to BCI and the other relating pregnancy to the original variables entered as factors (i.e., pregnancy $=$ stomach fat + kidney fat + brisket fat + back fat + femur marrow). These models were compared using Akaike's Information Criterion (AIC). Immature female caribou (yearlings and calves) were omitted from the analysis. Hunters prefer to harvest adult female caribou during late winter both because of their superior body fatness and for the caribou fetus, which is considered a delicacy.

\section{RESULTS}

\section{Evaluation of Female Caribou Body Condition}

Adult female caribou body condition was sampled from 1 March to 1 May in 2000 and from 11 February to 27 April in 2001. Samples were collected from 217 adult female caribou, 41 harvested by 11 hunters in 2000 and 176 harvested by 34 hunters in 2001. In 2000, most samples $(85 \%)$ were from Nonacho Lake $\left(55^{\circ} 10^{\prime} \mathrm{N}, 110^{\circ} 10^{\prime} \mathrm{W}\right), 80$ $\mathrm{km}$ southeast of Łútsël K'é, while in 2001, 84\% of the samples were within a $25 \mathrm{~km}$ radius of Łútsël K'é.

\section{Calibration of Hunters' Impressions with Body Condition Indices}

Strong relationships existed between hunters' impressions of female caribou body condition and each of the body condition categories measured (i.e., fat from stomach, kidney, brisket, and back, and colour/texture of femur marrow; Table 2). Hunters in this study made consistent assessments of body condition in both survey years (i.e., animals with the same or similar body condition rating that were considered skinny by the hunters in 2000 were also considered skinny in 2001), even though differences in kidney and brisket fat quantities between 2000 and 2001 were detected (Kidney fat: Model 2; Brisket fat: Model 2; Table 2).

The predicted probabilities suggest that hunters were able to distinguish between animals of different body condition quite well. For example, a female caribou that hunters considered "skinny" has no chance of having "lots" of stomach fat and a $68 \%$ chance of having "none" (Table 3). It would be expected to have "some" kidney fat or "none," most likely the former. It has a $16 \%$ chance of having brisket fat and only a $2 \%$ chance of having back fat. The chance that an animal had cream-coloured and solidtextured femur marrow increased as the hunters' impression of body condition improved, although even an animal that was considered skinny had an $82 \%$ chance of having cream/solid marrow (Table 3).

In contrast, there was no chance that an animal the hunters considered "fat/really fat" would not have stomach, kidney, or brisket fat. There would be a small possibility that the animal might have no back fat or pink/greasy 
TABLE 3. Predicted probabilities (as determined by Model 3) for the relationship between female caribou body condition indices and hunters' impressions.

\begin{tabular}{|c|c|c|c|c|}
\hline \multicolumn{2}{|c|}{ Body condition index } & \multicolumn{3}{|c|}{ Hunter's impression category } \\
\hline Class & Fat rating & Skinny & Not so bad & Fat/Really fat \\
\hline \multirow{3}{*}{ Stomach } & None & 0.68 & 0.05 & 0.00 \\
\hline & Some & 0.32 & 0.70 & 0.30 \\
\hline & Lots & 0.00 & 0.25 & 0.70 \\
\hline \multirow[t]{3}{*}{ Kidneys } & None & 0.25 & 0.03 & 0.00 \\
\hline & Some & 0.75 & 0.97 & 0.76 \\
\hline & Covered & 0.00 & 0.00 & 0.24 \\
\hline \multirow[t]{3}{*}{ Brisket } & None & 0.84 & 0.28 & 0.00 \\
\hline & $0-.5$ inch & 0.16 & 0.72 & 0.81 \\
\hline & $>.5$ inch & 0.00 & 0.00 & 0.19 \\
\hline \multirow[t]{3}{*}{ Back } & None & 0.98 & 0.70 & 0.02 \\
\hline & $0-.5$ inch & 0.02 & 0.30 & 0.43 \\
\hline & $>.5$ inch & 0.00 & 0.00 & 0.55 \\
\hline \multirow[t]{2}{*}{ Marrow } & Pink/Greasy & 0.18 & 0.09 & 0.03 \\
\hline & Cream/Solid & 0.82 & 0.91 & 0.97 \\
\hline
\end{tabular}

femur marrow, or both (Table 3). Nearly all "fat/really fat" adult female caribou had cream/solid femur marrow, but only about a quarter had kidneys totally covered by fat, and just over two-thirds of them had "lots" of stomach fat (Table 3). At the same time, slightly more than half of the "fat/really fat" adult female caribou had more than $.5 \mathrm{inch}$ of back fat, and almost one-fifth had more than .5 inch of brisket fat (Table 3$)$.

\section{Relationship between Body Condition and Pregnancy Probabilities}

No difference $\left(\chi^{2}=1.858\right.$, df $\left.=1 ; p=0.173\right)$ was detected between pregnancy rates for adult female caribou harvested in late winter $2000(83 \%, \mathrm{n}=41)$ and 2001 $(90 \%, \mathrm{n}=176)$. BCI and hunters' impressions were significantly related to pregnancy probabilities in both years (Table 4). The logistic models indicated that females with greater fat deposits had a higher probability of being pregnant (Fig. 2a, b; refer to line graph). The AIC values indicated that the $\mathrm{BCI}$ model $(\mathrm{AIC}=121.8)$ was preferable to the model in which the original five variables (i.e., stomach, kidney, brisket, back, marrow) were individually entered as factors (AIC $=134.1$ ). Allowing for the extra variables in the more detailed model did not provide a better fit to the data.

\section{Annual Variation in Female Caribou Body Condition}

Estimates from the BCI $\left(\chi^{2}=16.195, \mathrm{df}=4 ; p=0.003\right)$ and hunters' impressions $\left(\chi^{2}=60.267, \mathrm{df}=3 ; p<0.001\right)$ indicated that the adult female caribou harvested were in better condition in late winter 2000 than in 2001 (Fig. 2). For this analysis, BCI ratings were grouped (i.e., 6-7, $8-9,10-11,12-13,14-16)$ because 10 expected counts from the original data format were lower than 5 , which made the chi-square approximation unreliable. Body condition index ratings 5 and 17 were not included because no counts were recorded in 2000 or 2001. Evidence for a "year" effect was detected in the kidney and brisket fat classes when the relationship between BCI and hunters' impressions was modeled (Table 2; Model 2).

\section{DISCUSSION}

\section{Use of Body Condition Indices to Monitor Herd Health}

Aboriginal hunters use subjective assessment of multiple sites on a caribou to appraise an animal visually, both before it is shot and when it is dressed out (Kofinas et al., 2003). Fat has traditionally been an important component in the diets of aboriginal peoples in the Subarctic and Arctic regions. Therefore, indigenous hunters are very conscious of an animal's likely fatness as it relates to sex and age class at a given season of the year. When the opportunity presents itself, hunters will select animals accordingly from those sex and age classes. The majority of animals are harvested for personal consumption, so fat animals are desirable.

Hunters' impressions were found to be a reliable predictor of caribou body condition. Their impressions of animals with a particular body condition rating did not vary between the two years. This indicates that hunters do not adjust their impressions to the general condition of the animals in any particular year (Table 2). It is possible to approximate the amounts of fat that an adult female caribou will have at each of the five sites considered here from hunters' impressions of the relative fatness of the animal while dressing it out in the field (Table 3). It would be preferable to have more than two years of body condition data; however, there is a strong indication that body condition of caribou could be monitored on the basis of hunters' field impressions alone. 
TABLE 4. Coefficients and level of significance associated with the relationship between the probability of pregnancy for female caribou in late winter 2000 and 2001 and (1) hunters' impressions and (2) body condition index (BCI).

\begin{tabular}{lcccc}
\hline \hline Predictor & Coefficient & SE Coefficient & t-ratio & $p$-value \\
\hline Impression 2000 & & & & \\
Skinny & -2.88 & 0.764 & -0.38 & 0.706 \\
Not so bad & 1.99 & 1.08 & 1.84 & 0.066 \\
Fat/Really fat & 3.28 & 1.28 & 2.57 & 0.010 \\
Impression 2001 & & & & \\
Skinny & 1.455 & 0.420 & 3.47 & $<0.001$ \\
Not so bad & 0.825 & 0.547 & 1.51 & 0.131 \\
Fat/Really fat & 2.26 & 1.08 & 2.08 & 0.037 \\
BCI 2000 & 0.7080 & 0.2696 & 2.63 & 0.009 \\
BCI 2001 & 0.8413 & 0.2133 & 3.94 & $<0.001$ \\
\hline \hline
\end{tabular}

Impressions of adult female caribou body condition collected from Łútsël K'é hunters in the field were similar to their general impressions recorded in interviews back in the community after winter (Kofinas et al., 2001). Therefore, it may be possible to use hunters' impressions reported in end-of-season interviews to calculate a BCI and an estimate of caribou productivity. The purpose for developing this relationship would be for use in communities that, for some reason, such as financial constraints, could not obtain impressions of body condition except by interviewing hunters after the winter hunting period.

Subjective indices (i.e., body condition score, or BCS) used by biologists in other studies have proven to be a reliable measure of caribou fatness (Gerhart et al., 1996). Similarly, the calculation of BCI from multiple body condition sites on each animal should reduce the effects of variation from patterns of fat mobilization and deposition that may exist between sexes and age groups and among subspecies (Huot and Goudreault, 1985; Gerhart et al., 1996). It was thought that the sum of these indices would provide a better overall assessment of body condition than the index from just one body site. The selection of body condition indices used to determine BCI was based on past experience of caribou biologists (Kofinas et al., 2001). Trade-offs between the objectivity and scale of the measure, ease of data collection, and the acceptability of the measurement techniques to Dënesóline hunters were considered.

Both body condition assessment techniques indicated that adult female caribou harvested in 2000 were fatter than those harvested in 2001. However, it would be difficult to draw any solid ecological or demographic conclusions from only two years of information. If body condition were monitored over a longer time, any trends that emerged could potentially be linked to changes in climate, population, range characteristics, or human activity.

The area over which the caribou were sampled would become important to avoid a geographic variation effect. It would be difficult to draw conclusions regarding general herd condition if animals were surveyed from only one area of the

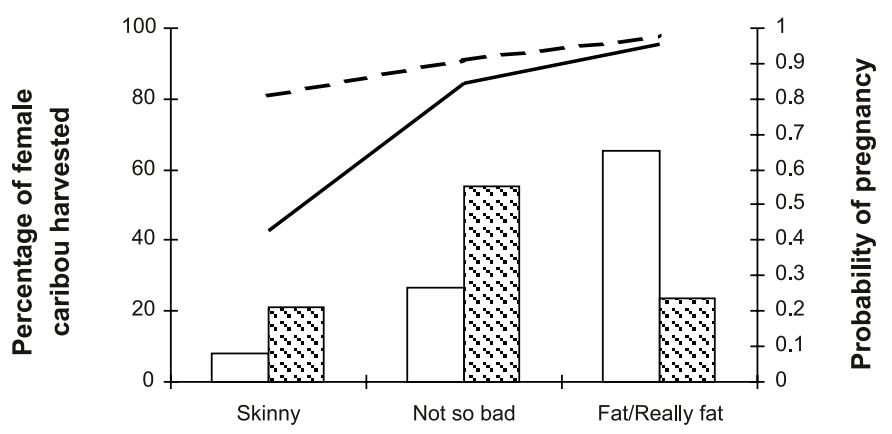

Hunters' impressions

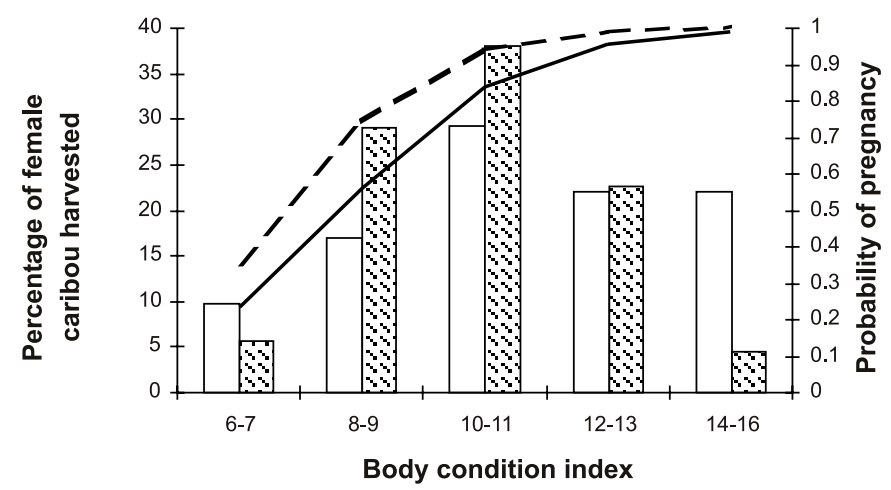

FIG 2. Frequency distribution in adult female caribou body condition (bar graph), and the probability of pregnancy (line graph) in late winter 2000 (white bar, solid line) and 2001 (gray bar, dashed line). Coefficients presented are for logistic equations of the form: $\mathrm{P}\left(\mathrm{x}_{\mathrm{i}}\right)=1 /\left(1+\mathrm{e}^{-\mathrm{x}^{\prime} \beta}\right)$, where $-\mathrm{x}^{\prime} \beta=\beta_{0}+\beta_{1} \mathrm{x}_{1}$, and $\mathrm{P}\left(\mathrm{x}_{\mathrm{i}}\right)$ is the probability of pregnancy at a particular $\mathrm{x}_{1}$.

winter caribou range. Thomas and Kiliaan (1998a) observed variation in body condition between two segments of the Beverly caribou herd that had overwintered in different parts of the range. Satellite collar data indicated that adult female caribou from the Bathurst herd overwintered in two separate geographic areas in 1999-2000 (Fig. 1; Gunn et al., 2001). Although no formal comparison was made, Łútsël K'é hunters reported that during late winter 2000, female caribou around McKinley Point on Great Slave Lake were thinner than cows located about $150 \mathrm{~km}$ to the southwest around Nonacho Lake. Ideally, body condition information should be obtained from as many communities from different parts of the caribou range as possible to reduce the effect of geographic variation.

At the very least, hunter impressions of caribou body condition can be a "red flag" indicator of herd health. For example, if hunters rarely or never harvest fat caribou, it is likely that most of the caribou in that area are nutritionally stressed. In contrast, if hunters rarely or never harvest a thin caribou, one could surmise that there are enough fat individuals in the population to satisfy hunter demand.

\section{Body Condition as a Predictor of Reproductive Potential}

Caribou body condition significantly affects reproductive potential and is therefore an important management consideration. As noted in previous body condition studies (Cameron et al., 1993; Gerhart et al., 1996; Thomas and 
Kiliaan, 1998b), the probability that a harvested adult female caribou was pregnant increased as its body condition estimate increased (Fig. 2). This relationship with reproductive potential was consistent for both techniques of fat assessment.

Cameron et al. (1993) found that the parturition rate of adult female caribou from the Central Arctic herd was largely predetermined at breeding by fall body condition. Thomas and Kiliaan (1998b) found it was possible to determine a fecundity-body condition relationship for cows from the Beverly caribou herd from late winter (March) estimates between 1980 and 1987, although findings from this study suggest that the slope of the relationship may vary between years. A less variable relationship may be observed if fall (October) body condition indices for adult female caribou are used. However, sampling is largely limited by the harvest behaviour of hunters.

We used fat deposition to track pregnancy, rather than alternatives such as hormonal assays, because hunters focus on this characteristic as they dress out animals. Thus the relative assessment is easy to make and does not interfere with the hunters' usual hunting behaviour (as opposed to asking them to collect fecal samples, or jaw samples to measure mandibular fat, for assessment).

The use of body condition as a predictor of pregnancy is unnecessary if the presence or absence of a fetus can be observed. However, hunters from some northern communities do not like to report harvesting pregnant females because they fear that public pressure through government legislation might force them to change harvesting practices (A. Kendrick, pers. comm. 2002). Their apprehension stems from previous attempts to limit aboriginal harvests through proposed amendments and law changes when caribou herds were believed to be declining (Fumoleau, 1975; Cranston-Smith, 1995). Reporting body condition may be more acceptable to some hunters. In this case, a herd-specific, body condition-pregnancy model would be beneficial. In addition to predicting fecundity, changes in body condition may be useful for flagging environmental perturbations and demographic fluctuations in caribou herds.

\section{Potential Limitations and Bias of the Monitoring System}

A monitoring system that uses data from caribou harvested by indigenous hunters is influenced by the hunters' selection of particular animals at certain times of the year. Łútsël K'é hunters prefer female caribou in late winter and bulls in fall (before the rut) because each is relatively fatter than the other during those times. These preferences may not coincide with the optimum sampling period indicated by the statistical models. Although hunters target animals they believe are likely to be the fattest, this potential bias can be accounted for if hunters are consistent with their selection criteria. As a result, body condition indices obtained from harvested caribou are relative rather than absolute. At times when female caribou were disturbed or in small isolated groups, harvests actually became quite random as hunters took what was available or closest. Łútsël K'é hunters target adult female caribou during late winter, so age structure was not considered to have an effect on pregnancy estimates. The few yearlings that were harvested during this study were not included in the analysis. The inclusion of yearlings in future samples seemingly could bias pregnancy estimates if it goes undetected.

Geographic and temporal (early vs. late season) differences in fat deposition are also potential sources of bias for body condition assessment. Body condition estimates could be further confounded by differences in the way hunters from different communities assess caribou body condition. In areas like Łútsël K'é, overlap in the winter ranges of several caribou herds (Bathurst, Beverly, Ahiak (Queen Maud Gulf), and Qamanirjuaq) can also make it difficult to identify which herd an animal came from. In April 2000, the Department of Resources, Wildlife and Economic Development used DNA analysis based on genotypes at eight microsatellite loci to determine that $60 \%(n=24)$ of adult female caribou in the Nonacho Lake region were genetically more similar to Bathurst caribou than to Beverly caribou (K. Zittlau, pers. comm. 2002). Records from satellite-collared Bathurst cows during this period were consistent with results of the DNA analysis (Gunn et al., 2001). Even so, the overlap with known winter ranges of the other herds mentioned above may have occurred, and animals harvested by Lútsël K'é hunters in 2001 could have been from any of these herds. This is a consideration, as each herd (or even different segments of the same herd) may have experienced different environmental stresses during the year. Therefore, a sample from more than one herd-or even a sample that is geographically restricted within one herd-could distort the picture.

Accuracy among assessors was not formally evaluated in this study, although the effect was assumed to be minimal. Only three observers were involved with measuring body condition indices, and one of them collected $88 \%$ of the records analyzed. Also, the semi-objective nature of the indices meant measurements were reasonably definitive (i.e., back fat: none, up to $.5 \mathrm{inch}$, more than .5 to $1 \mathrm{inch}$, more than 1 inch). However, some limited personal judgement could occur at borderline values when trying to make exact measurements during inclement weather. The stomach fat estimate was the only subjective measure. It is hoped that training of personnel reduced this variability.

\section{Management Implications}

Scientific caribou body condition studies are often limited by small sample sizes. Inclusion of hunters' knowledge and data from thousands of harvested caribou could substantially increase the sample size and expand the geographic area sampled. Annual harvests are estimated to be about 40000 caribou from the George River herd, 14000 to 18000 from the Bathurst herd, 2600 to 3900 from the Porcupine herd, and 15000 to 20000 from the Western 
Arctic herd (Porcupine Caribou Management Board, 2001; J. Dau, pers. comm. 2002; Kofinas et al., 2003).

If hunters are asked to report body condition data regularly, measurements must be quick, uncomplicated, and easily replicated. It is unlikely that hunters will assess each animal in a way that allows BCI to be measured. At best, it may be possible to gain hunters' impressions of each animal. A hunter's ability to predict body condition is not affected by how fat accumulates at a particular site. Results from this study indicate that limited trade-offs with accuracy of fat measurements can sometimes be made for a potentially large body of data. Absolute measures of fat may not be necessary if temporal trends in body condition satisfy management needs. This depends largely on whether the program is used as a general monitoring method or as a tool for predicting fecundity and other demographic parameters, such as calf survival.

Detailed body condition information could be obtained from samples of harvested caribou if locally trained observers accompanied hunters into the field. Again, measurement techniques would have to be quick and unobtrusive to the hunter, and their results must be repeatable. Adverse weather conditions in late winter often make it difficult to record precise measurements quickly; therefore, the use of indices would probably be favoured.

Involving hunters in monitoring the well-being of caribou herds extends beyond reporting fat quantities. In this study, hunters identified the brisket as an important site that should be monitored when body condition is assessed. Also, the hunters' past and current experiences on the land could provide valuable baseline information for determining what causes changes in body condition or herd health. Hunters could provide details regarding changes in caribou movements, numbers, and behaviour or changes in environmental conditions (e.g., relative snow depths between years and icing on, in, and under the snow pack).

Canadian federal, provincial, and territorial governments have increasingly recognized the value and longterm viability of involving aboriginal stakeholders in resource management. Also, indigenous groups have assumed management decision-making roles through the comprehensive land-claim process (e.g., Inuvialuit Final Agreement, 1984) and external co-management boards (e.g., Beverly Qamanirjuaq Caribou Management Board, 1982; Bathurst Co-management Planning Committee, 1998). These processes are laying the foundation for making greater use of indigenous knowledge in wildlife management and for building trust and confidence between users and managers. Monitoring of caribou fatness by aboriginal hunters provides an ideal opportunity for northern communities and the scientific sector to manage a vital wildlife resource collaboratively.

\section{ACKNOWLEDGEMENTS}

Special thanks must go to the people of Łútsël K'é, the Łútsël K'é Lands, Wildlife, and Environment Committee, and the Łútsël K'é Dëne Band Council for allowing this research to occur within their community. My thanks to R. Marlowe and E. Boucher for assisting with data collection in the field. Thank you to F. Berkes for providing guidance and support. The project was funded primarily by New Zealand's Foundation for Research, Science, and Technology. Funding also was received from F. Berkes, University of Manitoba. Swazi Apparel, New Zealand, kindly supplied clothing for fieldwork. Logistic support was received from the Łútsël K'é Dëne Band, T. Coles (Łútsël K'é Northern Co-op), and the Royal Canadian Mounted Police stationed in Łútsël K'é between 1999 and 2001. Thanks also must go to the anonymous referees for their review of an earlier version of this manuscript; to R. Webster, A. Demers, and M. Manseau for their statistical advice; and to A. Kendrick for her historical information.

\section{REFERENCES}

ALLAYE CHAN-McLEOD, A.C., WHITE, R.G., and RUSSELL, D.E. 1999. Comparative body composition strategies of breeding and nonbreeding female caribou. Canadian Journal of Zoology 77(12):1901 - 1907.

BERKES, F. 1998. Indigenous knowledge and resource management systems in the Canadian Subarctic. In: Berkes, F., and Folke, C., eds. Linking social and ecological systems: Management practices and social mechanisms. Cambridge: Cambridge University Press. 98-128.

CAMERON, R.D. 1994. Reproductive pauses by female caribou. Journal of Mammalogy 75:10-13.

CAMERON, R.D., SMITH, W.T., FANCY, S.G., GERHART, K.L., and WHITE, R.G. 1993. Calving success of female caribou in relation to body weight. Canadian Journal of Zoology 71:480486.

CRANSTON-SMITH, V.V. 1995. Chipewyan hunting, scientific research, and state conservation of the barren ground caribou, 1940-1970. Master's thesis, Department of Native Studies, University of Saskatchewan, Saskatoon.

FUMOLEAU, R. 1975. As long as this land shall last: A history of Treaty 8 and Treaty $11,1870-1939$. Toronto: McClelland and Stewart Ltd.

GERHART, K.L., WHITE, R.G., CAMERON, R.D., and RUSSELL, D.E. 1996. Estimating fat content of caribou from body condition scores. Journal of Wildlife Management 60(4):713-718.

GERHART, K.L., RUSSELL, D.E., VAN DE WETERING, D., WHITE, R.G., and CAMERON, R.D. 1997. Pregnancy of adult caribou (Rangifer tarandus): Evidence for lactational infertility. Journal of Zoology 242:17-30.

GUNN, A., DRAGON, J., and BOULANGER, J. 2001. Seasonal movements of satellite-collared caribou from the Bathurst herd. Final Report to the West Kitikmeot/Slave Study Society. Yellowknife: Wildlife and Fisheries Division, Resources, Wildlife and Economic Development, Government of the Northwest Territories. 
HUOT, J., and GOUDREAULT, F. 1985. Evaluation of several indices for predicting total body fat of caribou. In: Meredith, T.C., and Martell, A.M., eds. Proceedings of the Second North American Caribou Workshop. McGill Subarctic Research Paper No. 40. Montreal, Quebec: Centre for Northern Research Studies, McGill University. 157-175.

KOFINAS, G., RUSSELL, D., and WHITE, R. 2001. Proceedings of the Body Condition Monitoring Technical Workshop, 16-18 February 2000, Whitehorse, Yukon, Canada. http:// www.dartmouth.edu/ arctic/rangifer/wahtek/

KOFINAS, G., LYVER, P.O'B., RUSSELL, D., WHITE, R., NELSON, A., and FLANDERS, N. 2003. Towards a protocol for community monitoring of caribou body condition. Rangifer $14: 43-52$.

PARLEE, B. 1998. Community-based monitoring: A model for northern communities. Master's thesis, University of Waterloo, Waterloo, Ontario, Canada.
PORCUPINE CARIBOU MANAGEMENT BOARD. 2001. Porcupine Caribou Management Board Special 15th Anniversary Edition. Whitehorse, Yukon.

SMITH, J.G.E. 1978. Economic uncertainty in an "original affluent society": Caribou and caribou eater Chipewyan adaptive strategies. Arctic Anthropology 15(1):68-88.

THOMAS, D.C. 1982. The relationship between fertility and fat reserves of Peary caribou. Canadian Journal of Zoology 60: 597-602.

THOMAS, D.C., and KILIAAN, H.P.L. 1998a. Fire-caribou relationships: (I) Physical characteristics of the Beverly herd, 1980-87. Canadian Wildlife Service Technical Report Series 309. Edmonton, Alberta. 178 p.

1998b. Fire-caribou relationships: (II) Fecundity and physical condition of the Beverly herd. Canadian Wildlife Service Technical Report Series 310. Edmonton, Alberta. 96 p. VENABLES, W.N., and RIPLEY, B.D. 1997. Modern applied statistics with S-PLUS. 2nd ed. New York: Springer-Verlag. 